\title{
Observed Best Practices Within a Student Driven Multidisciplinary Team- based Architectural Engineering Capstone
}

\section{Dr. Ryan L. Solonsky P.E., Pennsylvania State University, University Park}

Ryan Solnosky is an Assistant Teaching Professor in the Department of Architectural Engineering at The Pennsylvania State University at University Park. Dr. Solnosky started at Penn State in July of 2013 and has taught courses for Architectural Engineering, Civil Engineering, and Pre-Major Freshman in Engineering. He received his integrated Professional Bachelor of Architectural Engineering/Master of Architectural Engineering (BAE/MAE) degrees in architectural engineering from The Pennsylvania State University, University Park, PA, in 2009, and his Ph.D. in architectural engineering from The Pennsylvania State University, University Park, PA in 2013. Dr. Solnosky is also a licensed Professional Engineer in PA. Ryan is also an advisor for Penn State's National AEI Student Competition teams where under his guidance students have won over 45 awards in the last 6 years. His research interests include: integrated structural design methodologies and processes; Innovative methods for enhancing engineering education; and high performing wall enclosures. These three areas look towards the next generation of building engineering, including how systems are selected, configured and designed.

Prof. M K Parfitt 


\title{
Observed Best Practices for Student Driven Multi-disciplinary Team-based Architectural Engineering Capstone
}

\begin{abstract}
The design, construction, and operations of buildings fall within the architecture and engineering domains. Buildings are highly technical and critical systems that are engineered to performance levels that allow buildings to function for 100's of years. To achieve this, buildings require engineers and managers to be of a learned, regulated and licensed profession. While many engineering degrees educate building design, perhaps best suited for the task is Architectural Engineering. Here at Penn State University, architectural engineering (AE) encompasses: Mechanical HVAC Design, Lighting/electrical Design, Structural Design and Construction Engineering and Management.

The pinnacle of the program is the yearlong capstone with inherent multidisciplinary aspects to it. With an industry interface, the capstone is critical to enrich the student experience in complex building design through simulating the project to be "more real world" than traditional capstones. This capstone distinguishes itself by the level of relatively independent work done by the student teams (vs. teaching by the faculty), heavy industry practitioner interactions, mentoring roles of the faculty and lastly, utilizing real industry projects. Original contributions for this study lie in having an open-ended design project where multi-disciplinary teams within AE are expected to develop project specific goals; select proper technologies, processes and infrastructures to support achieving these goals; then performing parametric and integrative design evolutions through cyclic iterations that focus on the goals and not specific disciplines. This paper describes trends and successes we have observed throughout our 9 years of offering this team based approach. Specifically how technology and collaborative processes were approached by the students, students' results on the topic, industry practitioner engagement strategies, and best practices for future implementation of similar offerings by other programs will be covered.
\end{abstract}

\section{Introduction}

Most degree programs that teach building engineering have design opportunities are often less than ideally constructed to reflect practical careers due to relatively few faculty members being trained, or they have no similar industry experience necessary to guide students [1]. Consequently in these settings, only a surface level understanding of their value is realized [2]. Many engineering students do not know how to approach large complex systems due to their exposure to idealistic examples [3]. Additionally, they not capable of providing critical multi-disciplinary integration of their designs due to the isolated nature of topics in the classroom [4] [5]. Capstone courses provide a comprehensive evaluation of students' prior knowledge that is applied to real projects through individual and/or team based structures [6]. As such, a revitalized approach to capstones within building engineering is logical.

In response to the curricula needs on the topic of collaborative multi-disciplinary design, an industry foundation (The Thornton Tomasetti Foundation) supported a senior design capstone course that exposed future project managers to work on highly collaborative teams [7]. Based on the foundation's recommendation and an early pilot study [8], the material developed there transformed how one option for the capstone project within Penn State Architectural Engineering (AE) is conducted. The discussion of this paper reports of 9 years of implementing a multi-disciplinary AE capstone with recommendations for others to ensure results are at a high performance level. 


\section{A need for a Multi-disciplinary Capstones in AE Programs}

Senior capstone design courses are the culminations of most, if not all, accredited undergraduate engineering programs in an attempt to provide an authentic engineering design experience [9]. Here, individual and/or team based capstones provide a comprehensive evaluation [6]. Capstone design courses in architectural engineering (AE) are the positive result of industry pressure and ABET requirements [10]. As an AE curriculum's most visible attribute to students, capstone design courses provide a sense of importance in students to prepare them for their transition to professional practice [11]. These systems provide excellent mechanisms for developing new leaders amongst the cohort of graduating students [12].

Studies of engineering capstones have revealed much variation in terms of course duration, project sources, project funding, faculty involvement, and team assignments [13]. Factors influencing this quality include: the amount and type of involvement of outside professionals and experts with relevant design experience, length of the course (one or two semesters), student/faculty ratio in the class, the number of faculty involved who have significant engineering design experience, and available resources such as computer labs equipped with a full suite of modern design application software [14].

Desjardins et al. [15] has indicated that with the growth of multidisciplinary projects, where teams are assembled from different majors or from different emphasis areas are able to tackle more comprehensive projects. Salas et al. [16] adds to this in that these multi-disciplinary teams promote integration that allow for more complex projects to be undertaken. Multi-disciplinary capstones, particularly AE capstones, are often less than ideally constructed/executed due to relatively few faculty members having similar industry experience necessary to guide student teams through course projects. Based on Aly's [17] observation of students in a capstone course, students felt that working on their project gave them an opportunity to utilize their skills and put into practice all that they had learnt thus giving them a potential advantage in the job market over other entry level competitors without that experience.

While maintaining technical execution, students often require the acquisition of complementary technical expertise not covered in the official curriculum [18]. This combination of skills remains an area of study within engineering education that is still in need of further development and refinement for different majors [19]. Engineering collaboration within team settings must "move beyond the divide and conquer" approach (commonly observed) and instead operate in a dynamic and integrative mode that resembles the actual building industry [20]. Multi-disciplinary teams provide an excellent way to promote integration that allows for more complex projects to be undertaken [16]. These systems provide excellent mechanisms for developing new leaders amongst students once they graduate when structured properly [12].

\section{The AE Multi-disciplinary Capstone Basis}

The Architectural Engineering (AE) program drastically changed how it approached its capstone program in the 2009-2010 school year by developing an alternative to an individual student capstone project for architectural engineering students entering their $5^{\text {th }}$ year. Our new capstone formulation combines multidisciplinary teams employing an integrated team approach made up of the four disciplines for the depth of technical competency. Disciplines were connected through Integrated Project Delivery (IPD) concepts with supportive modeling technologies. These notions, coupled the foundation for team interaction on technical and "soft" topics. After the original adoption of the pilot program [8], the AE Dept. shifted focus from faculty selecting projects and moved to that of the National AEI Student Design Competition (NAEISDC). Here, the capstone teams use the NAEISDC project and requirements as the basis of their work. 
All architectural engineering students are in either in the Bachelor of Architectural Engineering (BAE) degree program or the integrated Bachelor of Architectural Engineering / Master of Architectural Engineering (BAE/MAE). Students dedicate four credits each semester or $25 \%$ of their course work for the academic year to this class. From a discipline standpoint, each team consisted of: construction, lighting/electrical, mechanical, and structural focused students (each housed in the AE department). Depending on the year and formulation of the projects, Teams consisted of 4 students (one in each discipline), 8 students ( 2 per discipline), or 10 students ( 2 per discipline plus two extra for the more challenging systems).

To meet the ABET demands for engineering graduates, a series of learning objectives were created specific to AE Teams. For relevance to the topic the specific objectives are listed below. The details on these 10 objectives are not discussed for brevity; instead please refer to [8].

1. Increase knowledge of discipline depth

2. Utilize previous knowledge of course work

3. Expansion of breadth and depth knowledge by self-learning

4. Gain a better understanding of how real projects are developed and designed

5. Mimic, through the project, how system design choices affect the other disciplines

6. Develop a team approach that takes precedence over individual disciplines

7. Gain a better understanding of the integrated process and the give and take aspects of design

8. Obtain a more powerful skillsets revolving around modeling tools

9. Develop proper work processes/paths

10. Expand the ability to research new technology and evaluate/implement this technology for a particular project.

Additionally, this course does not directly teach new technical knowledge, which is not common in most engineering capstones within the U.S. and, depending on the region, internationally [21]. All teaching in this setting is through guest speakers to supplement specific technical skills related to project challenges and core themes. Teams are directed towards researching given topics that are more cutting edge. Faculty help disseminate this knowledge if students ask. Faculty members are responsive to teaching topics in a "just in time" format when they see teams not understanding or missing particular knowledge.

With the course objectives known, the core components that comprised the multidisciplinary pilot program were formulated. Critical to the success of the capstone, critical areas are included in the following list below. Each of these areas are discussed in the following sections and each section gives recommendations on best practices and takeaways if readers want to adopt similar type courses. To provide a concise logical takeaway in each area, Tables were generated with best practices. These tables are the recommendations of the authors and instructors of the capstone have found other the last 9 years.

- Team Formulations

- Formulation of assignments

- Project Selection

- Faculty involvement as discipline consultants

- External guidance by practitioner representatives from industry

\section{Formulation of Assignments}

For this capstone approach, the faculty and Dept. moved away from traditional assignments that have specific deliverable requirements for exact topics. We instead opted for an open-ended assignments where teams selected appropriate areas of focus to design, all based on the requirements of a competition and/or 
the building type (i.e. hospital or office). Building design competitions often state project objectives and requirements that are technical yet broad to allow: team creativity, exploration into topics of interest, apply prior knowledge, and conduct appropriate research on the topic. These built-in requirements set the stage each year, as well as, make the faculty generate new schedules.

The assessment approach to our version of a student driven capstone is multi-faceted that encompasses: reports, presentations, consultations with faculty, and the surveys [7]. Evaluation procedures were formulated that allow for the measurement of technical and soft skills in students. Different metrics were established for the following four student content categories: 1) technical content; 2) soft skills; 3) course/project management and 4) team dynamics. Technical content and management categories focused on student deliverables whereas, team dynamics were the internal relationships within the team. The general timeline for when different assignments and assessments were deployed throughout the academics year is shown in Figure 1.

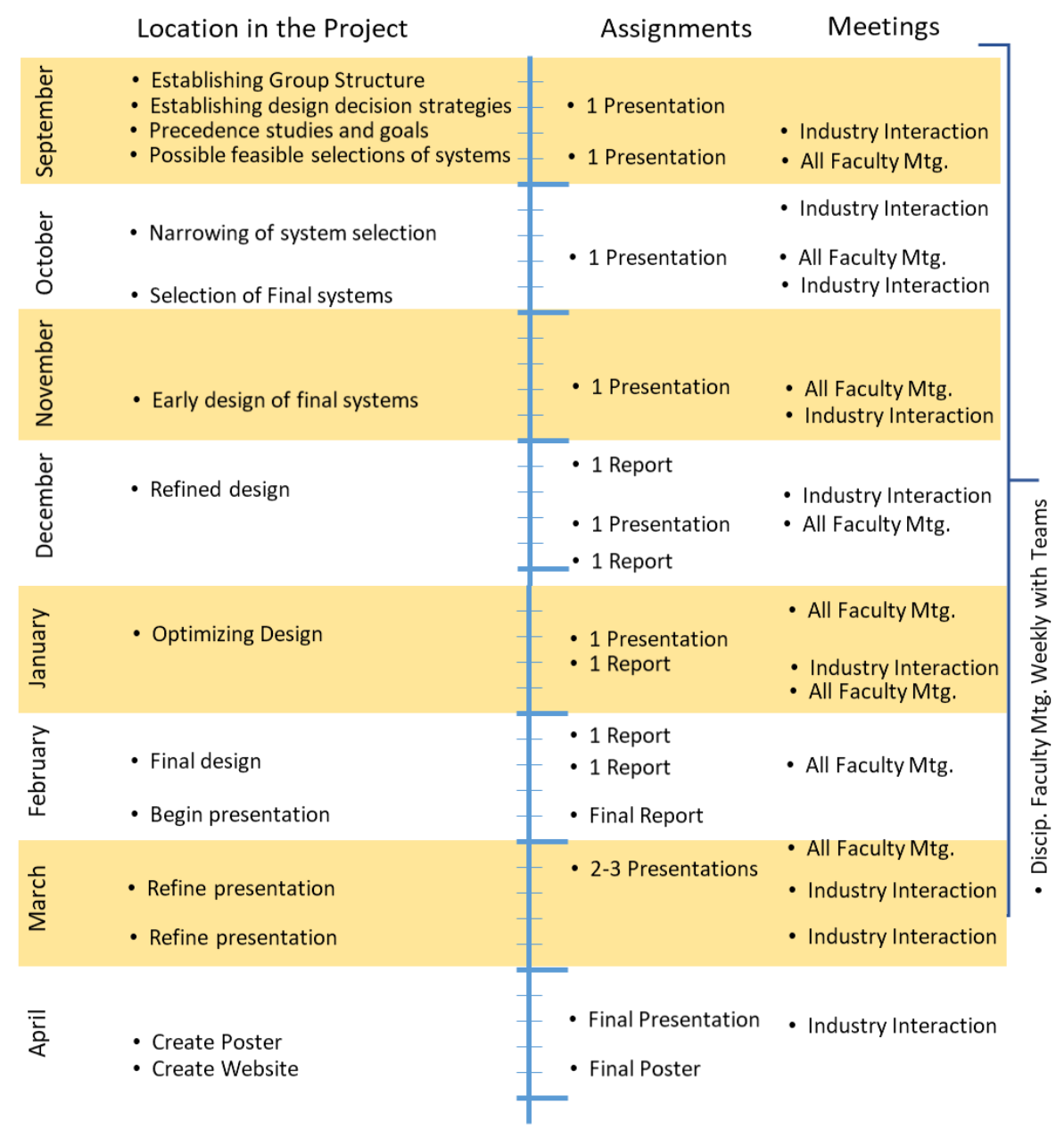

Figure 1: Schematic Timeline of, Student Work, Assessments, and Faculty Interactions.

To evaluate the technical and soft skill assignments, nine different metrics used which were provided to the students through discussion and a sharing of the actual final presentation grade assessment form. The list of metrics is provided below. In relating the metric areas back to the course objectives and student deliverables, Table 1 shows how they are inner connected. 
Table 1: Correlation between Metrics, Assessments, and Objectives

\begin{tabular}{|l|l|l|}
\hline \multicolumn{1}{|c|}{ Metric } & Assessment Format & Course Objective \\
\hline Discipline Technical Content & $\begin{array}{l}\text { Presentation } \\
\text { Reports }\end{array}$ & $1,2,3$ \\
\hline Technical Integration Content & $\begin{array}{l}\text { Presentation } \\
\text { Reports }\end{array}$ & $4,5,7,9$ \\
\hline Graphics & $\begin{array}{l}\text { Presentation } \\
\text { Reports } \\
\text { Course management }\end{array}$ & 5,8 \\
\hline Clarity of Work & $\begin{array}{l}\text { Presentation } \\
\text { Reports }\end{array}$ & 4,8 \\
\hline Demonstration of IPD/BIM & $\begin{array}{l}\text { Presentation } \\
\text { Reports }\end{array}$ & $1,2,4$ \\
\hline Amount of Effort & $\begin{array}{l}\text { Presentation } \\
\text { Reports } \\
\text { Course management }\end{array}$ & 3,10 \\
\hline Teamwork & $\begin{array}{l}\text { Presentation } \\
\text { Reports } \\
\text { Course management }\end{array}$ & $4,5,6,7,9$ \\
\hline Answering Questions & Presentation & 2,6 \\
\hline Presentation Skills & Presentation & 2,8 \\
\hline
\end{tabular}

To create meaningful designs and experiences of the students, several best practice takeaways can be learned and transferred from our experiences. Table 2 details both assignment best practices but several further course structure lessons learned from our offerings. These are particularly true when considering self-driven capstones like this one.

Table 2: Course and Assignment Structure Best Practices.

\begin{tabular}{|c|c|}
\hline Practice/Trait & Justification \\
\hline $\begin{array}{l}\text { A double semester is preferred as compared } \\
\text { to a single semester due to the complexity } \\
\text { and scope of student work. }\end{array}$ & $\begin{array}{l}\text { Shorter durations limit the amount of depth and focus students can develop. } \\
\text { Also collaboration and team efforts take time to develop and would be } \\
\text { minimized in one semester. }\end{array}$ \\
\hline $\begin{array}{l}\text { Focus of course is team project work time } \\
\text { rather than teaching }\end{array}$ & $\begin{array}{l}\text { Having the majority of class time being project work time is preferable as it gives } \\
\text { the simulation of practicing engineering firms. }\end{array}$ \\
\hline $\begin{array}{l}\text { Have teams develop a hierarchy of goals: } \\
\text { project/team, integrated and discipline } \\
\text { specific. }\end{array}$ & $\begin{array}{l}\text { Having a hierarchy allows students to identify common systems that are } \\
\text { interdependent on outcomes from others. } \\
\text { Keeps the team focused on the end result and provides scope during design } \\
\text { evolution. } \\
\text { It allows teams to more easily evaluate their designs. }\end{array}$ \\
\hline $\begin{array}{l}\text { Have students map the technology and } \\
\text { processes to the project focus areas or project } \\
\text { goals. }\end{array}$ & $\begin{array}{l}\text { at is necessary at any given } \\
\text { hooth and quick simulations. }\end{array}$ \\
\hline $\begin{array}{l}\text { Require a combination of reports, } \\
\text { presentations, calculations, } \\
\text { simulations as gradable material. }\end{array}$ & $\begin{array}{l}\text { By not having presentations, team limit their ability to concisely communicate } \\
\text { their ideas. } \\
\text { It makes faculty grading more difficult when we cannot see all aspects of student } \\
\text { work. } \\
\text { The quality of one area may be significantly different than other areas. }\end{array}$ \\
\hline $\begin{array}{l}\text { Require multiple technical presentations for } \\
\text { the final presentation. }\end{array}$ & $\begin{array}{l}\text { To get the best presentation that sound integrated, thorough, and professional, } \\
\text { require multiple draft presentation practices to faculty where they are evaluated } \\
\text { and critiqued. Critiquing should include: Content, wording, posture, graphics, } \\
\text { and flow/story telling. }\end{array}$ \\
\hline $\begin{array}{l}\text { Stray away from technical presentations that } \\
\text { isolate disciplines }\end{array}$ & $\begin{array}{l}\text { The presentations with the best industry feedback are ones that tell a story about } \\
\text { the design process, design evolution and why. Avoid segmented presentations } \\
\text { with one discipline talking. It is better to uses themes to tell the design. }\end{array}$ \\
\hline
\end{tabular}




\section{Project Selection}

Project selection is critical for the success of the capstone. Each year the project needs to have sufficient complexity that each discipline can apply skills developed from their previous studies. Without proper project attributes, certain discipline requirements that relate to required and potential analyses may not be realized, or worse, be feasible if the project is too simple or too difficult. Throughout the nine years of the student driven capstone, the AE dept. always ensured real building projects were used. Before utilizing the national competition format (NAEISDC), the dept. utilized the help of different architecture, engineering and construction companies to aid in getting an appropriate building with enough complexity and areas for design integration. Once the mechanism switched to the NAEISDC, the competition projects were used. While the faculty did not have control over the project in the NAEISDC, it remained a real project given to the NAEISDC by different sponsoring companies.

While allowing the faculty to select the project is ideal, competitions rarely offer this opportunity. Instead, the faculty should evaluate the appropriateness of the competition's project and requirements to determine if that competition is acceptable. Criteria that has been used for project selection with team members of the $4 \mathrm{AE}$ disciplines are highlighted in Table 3 . Along with the project, the faculty need to identify challenges that will scope the capstone/competition for the year. We have found that challenges that are realistic, relevant to current issues and geographic regions, and those that simulate common practices in industry are received the best by students and industry supporters. Additionally, the more multidisciplinary the challenge is, the more likely that the entire team buys into that challenge occurs. Table 4 shows the challenges adopted in our study by the competition format. These were all well received by the students.

Table 3: Predominant Criteria for Project Selection

\begin{tabular}{|l|l|}
\hline Building Focus & \\
\hline \multirow{5}{*}{ General } & $50,000-100,000$ GSF minimum \\
\cline { 2 - 2 } & Owner and project team that is supportive \\
\cline { 2 - 2 } & No more than 5 years old (potential code issue otherwise) \\
\cline { 2 - 2 } & Availability of digital models (baseline models) that are in current formats \\
\cline { 2 - 2 } & A project where variety of systems could be feasible \\
\cline { 2 - 2 } & Available local codes from municipalities \\
\cline { 2 - 2 } & Available utilities plans and rates for the area \\
\hline \multirow{5}{*}{ Structural } & $60 ` \geq$ high above grade or some unique configuration to force complex loadings \\
\cline { 2 - 2 } & Available geotechnical reports \\
\hline Lighting/Electrical & Variety in the types of spaces for different lighting conditions \\
\cline { 2 - 2 } & Opportunity for daylighting \\
\hline Mechanical & Opportunity for energy savings \\
\hline Construction & A semi-realistic to real project budget/final price \\
\cline { 2 - 2 } & A baseline construction duration \\
\hline
\end{tabular}

We have observed that when we properly consider the challenges listed (Table 3) along with projects that meet Table 4 closely, then the resulting student designs are better integrated, innovative and technically sound. We recommend other adopter to follow similar practices for project selections. 
Table 4: Reoccurring Project Challenges

\begin{tabular}{|l|c|}
\hline Challenge & Critical Disciplines Involved \\
\hline coexistence with surroundings & All \\
\hline energy efficient building & M, E, L \\
\hline Future adaptability & All \\
\hline Prototype Project (adaptable for Multi-locations) & All \\
\hline Safety & All \\
\hline Resiliency & S, M, E, L \\
\hline Enclosure & All \\
\hline Sustainability & All \\
\hline Emergency Disaster Planning & All \\
\hline Smart Building Technologies & M, E, L \\
\hline Well Building Standard & M, E, L \\
\hline Accelerated Construction & S, C \\
\hline Urban Construction & S, C \\
\hline Note: M: Mechanical, E: Electrical, L: Lighting, S: Structural, C: Construction, All: All disciplines equally
\end{tabular}

\section{Team Formulation}

To begin each capstone year, team membership needed to be determined. The authors first notified the entire capstone class a semester before the course would start. Here students learned what the program consisted of and the overall expectations for the course. Also at the meeting, guidelines and rules for team selection and the function of the course were discussed.

Faculty allowed self-generated volunteer student's teams for the project in all years tested. While there have been studies that support both self-selected teams and random-selected teams (by faculty), the AE faculty felt that teams would function faster and at a higher performance if they self-selected. From a discipline standpoint, each team had to consist of: construction, lighting/electrical, mechanical, and structural students (each housed in the AE department). Within each discipline there were a combination of students pursuing undergraduate degrees (B.A.E.) and students pursuing a combined undergraduate/graduate degree (B.A.E./M.A.E.). Having the B.A.E./M.A.E. students allowed for more complex analysis and design considerations; yet, upon reviewing work faculty found insufficient trends to indicate this had an advantage over those who did not. The typical team consisted of two from each option but, based on the competition, a 10 person team was permitted. The faculty only let 10 people on the team if the project was challenging enough and justifications were provided as to why the extra two members were wanted. Team selection best practices that have been observed over the years are detailed in Table 5.

Table 5: Team Selection Best Practices.

\begin{tabular}{|l|l|}
\hline \multicolumn{1}{|c|}{ Practice/Trait } & \multicolumn{1}{c|}{ Justification } \\
\hline $\begin{array}{l}\text { Teams need to have all disciplines } \\
\text { on the team by students studying } \\
\text { those focuses. }\end{array}$ & $\begin{array}{l}\text { Having students in one discipline try to be another discipline falls short in being able to } \\
\text { complete detailed technical designs. } \\
\text { Not having all disciplines also limits the amount of true integration of disciplines as } \\
\text { teams must guess or approximate missing solutions or simply exclude them. }\end{array}$ \\
\hline $\begin{array}{l}\text { In regards to overall team size, } 4 \\
\text { person teams or 8 person teams are } \\
\text { recommended. Note a } 4 \text { person is } \\
\text { one in each discipline, } 8 \text { is two in in each discipline works well and holds all accountable but in complex projects } \\
\text { each discipline. }\end{array}$ & $\begin{array}{l}\text { One in erkload can at times be overly demanding. 8 person teams allow for more detail and } \\
\text { internal collaboration. } \\
\text { More than } 8 \text { or more than 2 per discipline then conflicts can arise and accountability } \\
\text { falls. }\end{array}$ \\
\hline
\end{tabular}




\section{Faculty as Discipline Consultants}

Instructor participation is essential in capstones as they hold the course framework together for the students [18]. While the AE capstone was open ended and student driven, it was the faculty's job to be the day-to-day advisor of the student groups. Early communication between faculty, students, and practitioners was vital. As previously mentioned, faculty did not set specific assignments with requirements. Instead, faculty set reoccurring meetings and due dates with suggested levels of completeness. From here, faculty would direct students to explore new areas and/or refine designs as needed to complete their students set goals.

The AE department's capstone course has an atypical arrangement in how faculty teach the capstone course as compared to many other universities. Instead of there being a single faculty member or instructor who runs the entire course and is responsible for all aspects, the course utilizes many faculty members to account for the multi-disciplinary nature. There are between 6-7 faculty involved in the project; one for each of the four disciplines (while lighting and electrical are one student option, often 2 faculty are assigned) and one to two integration focused faculty. The two integration faculty were the individuals who looked at the team dynamics and guided the larger picture items ensuring designs were holistic, collaborative, and encompassing of all discipline considerations.

To provide the students with the best faculty interactions and to obtain solid results, the authors propose similar means of selecting faculty and having similar duties. Table 6 provides additional best practices we have learned over our 9 years of offerings that may help over programs.

Table 6: Faculty Consultant Best Practices

\begin{tabular}{|l|l|}
\hline \multicolumn{1}{|c|}{ Practice/Trait } & \multicolumn{1}{c|}{ Justification } \\
\hline Volunteer Faculty & $\begin{array}{l}\text { We have found that faculty who volunteer to advise the students are } \\
\text { more engaged and will to provide more comprehensive feedback. } \\
\text { Additionally, this version of the capstone does have more contact than } \\
\text { our prior individual consultations. }\end{array}$ \\
\hline Faculty Grading Format & $\begin{array}{l}\text { While each discipline provides a grade for technical merit, other } \\
\text { grading attribute need to be taken into account. Often soft skills are } \\
\text { done here on a mutually agreed upon consensus score that is determined } \\
\text { by a private but open faculty discussion. }\end{array}$ \\
\hline $\begin{array}{l}\text { Fast Grading Turnaround Time } \\
\begin{array}{l}\text { Integrated faculty member course should have } \\
\text { soderate to significant experience in working on } \\
\text { similarly structured multi-disciplinary teams. } \\
\text { Experience in project management is important. }\end{array}\end{array}$ & $\begin{array}{l}\text { If a competition is used fast grading turn around are need. These turn } \\
\text { around should be done within a week max and with as much detail as } \\
\text { possible to allow for time for corrections. } \\
\text { struggles to provide design assistance and experiences teams. Also } \\
\text { practice industry knowledge and project management experience for } \\
\text { realistic solutions may be lacking. }\end{array}$ \\
\hline $\begin{array}{l}\text { Per discipline, faculty need to meet regularly (1 per } \\
\text { week min.) to receive team updates, provide } \\
\text { feedback, provide technical support, and to teach } \\
\text { material (as needed). }\end{array}$ & $\begin{array}{l}\text { Regular faculty meetings are necessary to ensure technical accuracy, } \\
\text { provide real-time feedback and to answer questions to ensure teams are } \\
\text { making progress toward appropriate design solutions. }\end{array}$ \\
\hline $\begin{array}{l}\text { An all option faculty meeting (1 per month min.) is } \\
\text { needed to get updates and provide feedback at a larger } \\
\text { level and to steer ideas. }\end{array}$ & $\begin{array}{l}\text { This will ensure that all faculty involved are brought up to speed on the } \\
\text { project as a whole. May also identify areas that are needed in one } \\
\text { discipline that another discipline considered. }\end{array}$ \\
\hline
\end{tabular}

\section{Industry Practitioner Interactions}

In addition to the faculty, student teams were advised by practitioner and construction representatives working on the actual competition project, as well as, other experts whom the faculty and/or students sought out. In support of Dutson et al.'s [22] practitioner studies, participation by industry occurred in different ways, including: technical consulting and assistance in the evaluation of teams and design 
results. For this capstone, industry provided input on topics not previously presented to students; provided tours on the projects or related projects; and; provided input in system selection and alternative solution generation. The variety of industry "categories" included: engineering designers and managers, architecture designers and managers, owners, general contractors, and specialty contractors.

For students to have a positive benefit in interacting with industry professionals, we do recommend several practices be undertaken. These practices are listed in Table 7. Overall, a similar course needs a professional who is dedicated and enthusiastic about helping teams. If not then, that practitioner can hamper creativity and team spirit. Practitioners who are also vague to respond or don't understand academic exercises should be avoided. The best practitioners, in the authors' experience are those that come from your own program (alumnus).

Table 7: Industry Practitioner Best Practices

\begin{tabular}{|l|l|}
\hline \multicolumn{1}{|c|}{ Practice/Trait } & \multicolumn{1}{c|}{ Justification } \\
\hline $\begin{array}{l}\text { Faculty connection to } \\
\text { that practitioner }\end{array}$ & $\begin{array}{l}\text { The quickest and most interactive industry we have interacted with have come to be prior students of } \\
\text { the program. This can be attributed to their support given they have gone through the program. }\end{array}$ \\
\hline Variety of discipline & $\begin{array}{l}\text { While having a single company do sponsorship or agree at a larger scale involvement is great, having } \\
\text { experts on specific topics is far more beneficial just to their expertise and since they were willing to } \\
\text { help their commitment. }\end{array}$ \\
\hline Knowledge Experts & $\begin{array}{l}\text { Establish a network of experts across the domain that your project may take. In a typical year we have } \\
\text { used between 5-15 different and unique experts. }\end{array}$ \\
\hline Ways to interact & $\begin{array}{l}\text { While interaction with practitioners is often done face to face (and is preferred by many students), } \\
\text { other methods can include: online discussion forums, go meetings/skype, phone and email, panel jury, } \\
\text { etc. }\end{array}$ \\
\hline
\end{tabular}

\section{A Co-Location Studio Design Space}

A co-location studio design space was created for the teams to work and proactively support effective communication and collaboration. The co-location studio design was accessible only to the student teams and was equipped with technology and materials capable of simulating collaborative team settings (Figure 2). Having all four disciplines within the same workspace encouraged collaboration due to the accessibility of each team member. The latest configuration of the space houses:

- Multi-touch monitors and displays;

- Multiple computer work stations with large design spaces for document layout and meetings;

- A conference area with seating for all team members;

- Multiple white boards for conveying ideas and details;

- Lockers for students to store supplies;

- Mobile work stations with a large monitor for displaying computer models.
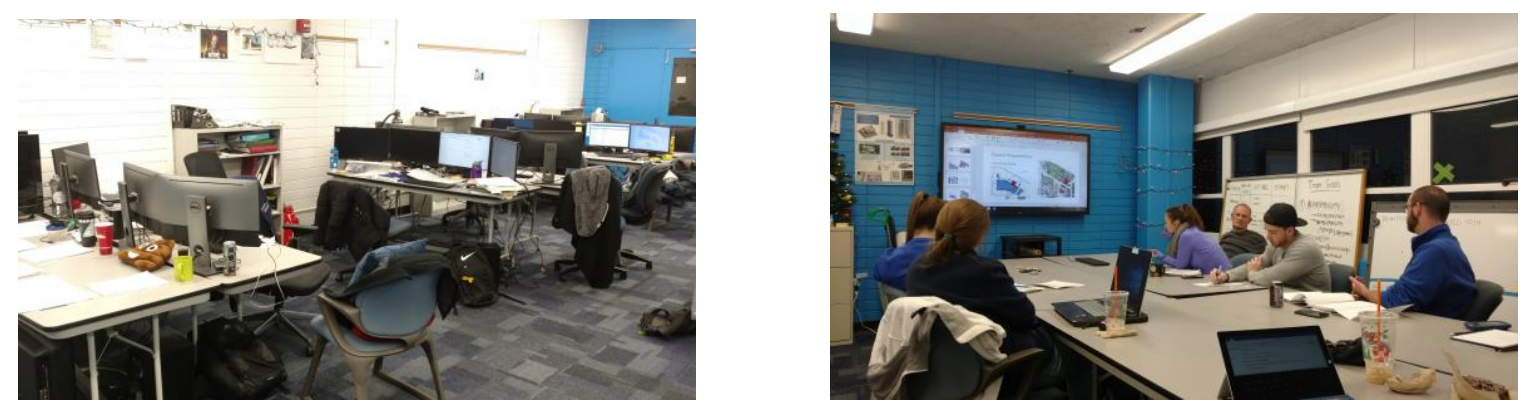

Figure 2: Images of the Space 
While the room had an initial layout, students were permitted to alter the configuration as long as it was approval. Approval was mostly for safety and power capacity concerns. It is highly recommended, if possible, to give the teams a dedicated space to be able to work in without the need to carry materials in every visit. This permanent setting allows teams to bond more but also doesn't slow down work. When designating the space, consider the best practices listed in Table 8. It is important to remember that not just the space needs consideration but also the technological support within the space.

Table 8: Studio Space Best Practices

\begin{tabular}{|l|l|}
\hline \multicolumn{1}{|c|}{ Practice/Trait } & \multicolumn{1}{|c|}{ Justification } \\
\hline $\begin{array}{l}\text { Teams should have a dedicated space to work in that promotes } \\
\text { collaboration and design completion. Spaces should consider the } \\
\text { following items: } \\
\text { - Desks and computers. } \\
\text { - Meeting areas/conference setting } \\
\text { - Presentation space/projectors } \\
\text { - White boards and cork pin boards. }\end{array}$ & $\begin{array}{l}\text { Proper spaces allow the teams to bond more and become } \\
\text { higher performing. We have also seen they spend } \\
\text { significant amounts of time outside of capstone class } \\
\text { time working on the project. An adequate sized and } \\
\text { equipped space encourages meeting and a more efficient } \\
\text { process. }\end{array}$ \\
\hline $\begin{array}{l}\text { Computational resources need provided that allow teams to } \\
\text { generate designs, convey designs, and collaborate. } \\
\text { Models are heavily used and computers need to be able to } \\
\text { effectively handle large files. }\end{array}$ & $\begin{array}{l}\text { A lack of these resources limits the design quality, the } \\
\text { presentation quality, and slows productivity. }\end{array}$ \\
\hline $\begin{array}{l}\text { Students need access to proper technical and industry standards } \\
\text { and codes. }\end{array}$ & $\begin{array}{l}\text { In order to design a real system, students need to be able } \\
\text { to access system and code requirements. }\end{array}$ \\
\hline
\end{tabular}

\section{Student Trends and How to Achieve Results}

In having conducted different iterations of how to structure student requirements and saying to students that a design must be something, faculty have felt that letting students develop goals then it results in more student commitment to the design. Part of this reasoning was to have students interact first hand with an open-ended project "problem" where they were to select all appropriate technology, methodologies, and goals needed to complete the project.

Students began by defining the project challenges prescribed in the competition program. Team then explored additional challenges as they felt necessary or in which the students had interest while defining project stakeholders. Once stakeholders and mandates in the program were established and understood, teams categorized them into specific project goals. Finally, the Team Project Goals are filtered and subdivided into discipline goals that support the Team Project Goals. To ensure that the design decisions were guided by the goals, teams evaluated the program requirements from the "owner" perspective regularly.

To understand the process of design and how teams execute design and software modeling within the project, each team developed strategies on how they would execute the designs. To maintain efficiency and progression, students needed to think out how the design was going to evolve and who was going to need each item at which phase. This led teams to quickly grasp the understanding that there is an inherent lead/lag on design information, as well as, there is a cyclic nature of design iteration and refinement. One of the more successful techniques used was last planner and pool planning to project ahead the items needing done, by whom, and when it had to be done.

Once a process was developed, teams had to establish how to narrow and select alternative design options objectively rather than by selecting what was most convenient either for the team or one given discipline. Teams have investigated a variety of ways to objectively select systems and/or narrow down possible alternatives without detailed engineering calculations. Based on this, teams would create a decision making matrix to help guide the design choices. This allowed for each of the team members to rank their 
alternative design options and receive a quantitative representation of the choices. Each project goal within a theme was weighted by the significance it had to the overall design process.

Student generated deliverables were of an expected quality, and often exceed the expectations, by the faculty. Technical assignments from the fall and spring semester generated a wide assortment of results from the teams. Through our 9 years of offering the capstone and with the earlier discussed challenges in conjunction with the iterative design cycle, reoccurring themes emerged. These themes can be grouped into 6 primary classifications:

- Systems integration across disciplines

- High performance of systems beyond code minimums

- Building Enclosures

- Natural and Manmade Disasters

- Optimization or reconfiguration of systems

- Advanced computer modeling technology

When attempting to classify student accomplishments, it became clear that solutions in one of the above classifications also fit within other categories due to significant overlap. This was viewed as a positive indicator that students were developing integrated systems from a design and construction standpoint. Systems integration across disciplines was the most collaborative among the classifications. Proposed designs often required the input of at least two disciplines of the team but had as many as all four providing input and design or construction considerations depending on the specific topic.

Being able to communicate information effectively can be challenging, particularly with the type of information being generated by the teams. Most traditional AE capstones develop working drawings (Denzer and Gardzelewski 2011), these drawings are often complex and do not readily demonstrate design results, or how the designs evolved. Faculty encouraged students to find creative ways to visually represent technical reasoning and process information.

The materials generated by the students over the years, as mentioned here, are strong indicators of the student driven multi-disciplinary capstone success. To be able to have results of this caliber, the earlier best practices were incorporated heavily. There are though other practices that didn't fall into the prior groups. These additional traits align with structuring deliverables and ensuring certain results from students are generated. See Table 9 for these recommendations.

Table 9: Best Practice Strategies for Achieving Similar Student Deliverables.

\begin{tabular}{|l|l|}
\hline \multicolumn{1}{|c|}{ Practice/Trait } & \multicolumn{1}{|c|}{ Justification } \\
\hline Detailed review of Student Goals & $\begin{array}{l}\text { To keep students focused and their designs remain technical and } \\
\text { appropriate, faculty need to scrutinize and help to refine their goals to } \\
\text { match the teams' intent. }\end{array}$ \\
\hline Group Ideas in themes & $\begin{array}{l}\text { Students often have a wide variety of ideas and topics they want to } \\
\text { explore then they first start. This is also true when they present and write } \\
\text { their designs up. To best convey the big picture, grouping designs and } \\
\text { ideas into themes significantly helps to tell the solutions' story. }\end{array}$ \\
\hline Establishing Objective Decision making Process & $\begin{array}{l}\text { To eliminate bias and opinions of students selecting the best solutions or } \\
\text { ones that are convenient, require students to objectively select solutions } \\
\text { based on decision making criteria to directly relate back to the goals. }\end{array}$ \\
\hline Technical Content Review & $\begin{array}{l}\text { Regular evaluation of technical solutions need to be examined by the } \\
\text { faculty so that time is not wasted. This can be done formally at set } \\
\text { points or in week discussions. }\end{array}$ \\
\hline Have both positive and improvement reflections. & $\begin{array}{l}\text { All projects have good and bad. External reviewers (industry) who see } \\
\text { the final results like to see the success but also some struggles students } \\
\text { have had. This helps students understand the industry is not easy. }\end{array}$ \\
\hline
\end{tabular}




\section{Discussion and Additional Best Practices for Future Adopters}

It was observed that student driven applications of integrated design in open-ended senior design capstone projects are effective when the right mechanisms and environments are in place. The implementation of these approaches, as well as, the softer processes and team development skills given to students through coaching, all served as a catalyst in the formulation of collaborative outcomes. When having students self-select topic areas and goals to study which they then design does have advantages in multidisciplinary settings. Holistically, it was shown and documented that student team driven formats are highly dependent on the students' prior knowledge of the topic, project type, and project challenge areas. Other factors that played a role were student/team interest in different building domains and technologies, the project types and whether the students had participated in a collaborative design effort previously.

In comparing the student results from teams in the new format to those of the old format, individual student capstones, there are distinct differences. Technical competency was maintained fairly uniformly between individual and team. Individuals had to do depth work (in their discipline option) and two smaller and broader designs in breadth work (outside of the discipline). Here is where the noticeable difference lie. Individual students often skimmed over the breadth requirements or didn't go into detail by looking at interactions with multiple systems. Teams had no true breadth but the daily interactions more than made up for the differences in the resulting final designs. Team project designs were more integrated and had solutions fully developed that were interconnected to multiple disciplines.

For other faculty to benefit from this formulation style in their capstones, several best practices can be taken away. Best practices that can better guide adopters to achieve integrative solutions on multidisciplinary architectural engineering teams were listed in Tables 2-9 in the paper's body. To properly facilitate a successful solution, some traits that may not be common in all academic faculty and / or institutions would need developed further. Critical is the evaluation of faculty and institutional resources before adopting such a course. Based on the experience and success gained in our past offerings, other programs can also succeed in a similar format outside of architectural engineering if a similar structuring is used and tested over time. Regardless of how the material presented in this paper would be applied to other capstones, the authors firmly believe that efforts to make capstones more industry and project focused where students drive the design and decisions will result in a better capstone experience that gives students a more realistic training.

Quantitatively or qualitatively students, faculty, and industry participants were surveyed and interviewed about their opinions, thoughts and critical areas of this style of capstone. While this paper only summarized best practices, positive data was collected and identified to support this paper's claims. As these results were already published, they were not included in this paper. For those interested in more detail on assignment structure, industry interactions, course development, team dynamics, and student trends, readers are encouraged to look into the following published works: [7], [8], and [23].

\section{References}

[1] Hannah, D. R., and Venkatachary, R. (2010). "Putting "organizations" into an organization theory course: A hybrid CAO model for teaching organization theory." Journal of Management Education, 34(2), 200-223.

[2] Hansen, R.S. (2006). "Benefits and problems with student teams: Suggestions for improving team projects." Journal of Education for Business, 82(1), 11-19.

[3] ASCE, (2009). Academic Council, Retrieved from http://content.aeinstitute.org/inside/academiccouncil .html (May 18, 2009). 
[4] Andersen, N., Yazdani, S., and Andersen, K. (2007). "Performance outcomes in engineering design courses." J. Prof. Issues Eng. Educ. Pract., Forum, January 2007, 2-8.

[5] ASCE, (2008). Civil Engineering Body of Knowledge for the 21st Century; Preparing the Civil Engineer for the Future. Second Edition, Reston, VA, ASCE.

[6] Jenkins, S.R., Pocock, J.B., Zuraski, P.D., Meade, R.B., Mitchell, Z.W., and Farrington J.J. (2002). "Capstone Course in an Integrated Engineering Curriculum" Journal of Professional Issues in Engineering Education and Practice, 128(2), 75-82.

[7] Parfitt, M.K., Holland, R.J., and Solnosky, R.L. (2013) "Results Of A Pilot Multidisciplinary BIM Enhanced Integrated Project Delivery Capstone Engineering Design Course In Architectural Engineering.” 2013 Architectural Engineering Institute National Conference, April 2013, University Park, PA, 43-52.

[8] Solnosky, R., Parfitt, M.K., and Holland, R. (2013) “An IPD and BIM Industry focused Capstone Course based on the AEC Industry Needs and Involvement", Journal of Professional Issues in Engineering Education and Practice, Special Issue: Curriculum Assessment and Continuous Improvement, doi: 10.1061/(ASCE)EI.1943-5541.0000157

[9] Farr, J., Lee, M., Metro, R., and Sutton, J. (2001). "Using a systematic engineering design process to conduct undergraduate engineering man- agement capstone projects. ” J. Eng. Educ. , 90(2), 193 - 197.

[10] Dougherty, J. and Parfitt, M. (2006) Enhancing Architectural Engineering Capstone Design Courses Through Web-Based Technologies. Building Integration Solutions: pp. 1-12. doi: $10.1061 / 40798(190) 49$

[11] Jones, S. A. and Houghtalen, R. (2000). "Using Senior Design Capstone as Model for Graduate Education". Journal of Professional Issues in Engineering Education and Practice, 126(2), 83-88.

[12] Rassati, G.A., Baseheart, T.M., and Stedman, B. (2010). "An Interdisciplinary Capstone Experience Using BIM," Structures Congress, 1689-1698.

[13] Stanford (2013). Harnessing New Technologies and Methods to Advance Teaching and Learning at Stanford and Beyond. Stanford Online, May, 2014

[14] Todd, R. H., Magleby, S. P., Sorensen, C. D., Swan, B. R., and Anthony, D. K. (1995).“A survey of capstone engineering courses in NorthAmerica."J. Eng. Educ., 84(2), 165-174.

[15] Desjardins, A., Millette, L., and Bélanger, E. (2010). "The challenge of teaching a multidisciplinary sustainable development capstone project.” Proc., 6th Int. CDIO Conf., CDIO, Ecole Polytechnique, Montreal, QB, Canada.

[16] Salas, E., Goodwin, G.F., and Burke, C.S. (2008). Team effectiveness in complex organizations: Crossdisciplinary perspectives and approaches. CRC Press.

[17] Aly, S. (2014). "Building Information Modeling (BIM) and its future in Undergraduate Architectural Science Capstone Projects" Proceedings from the 2014 BIM Academic Symposium, Washington D.C., January 11, 2014, 1-8.

[18] Anderson, D. and Mourgues, C. (2014). "Industry Participation in Construction Capstone Courses: A Company's Experience." Pract. Period. Struct. Des. Constr., 10.1061/(ASCE)SC.1943-5576.0000178, 73-76.

[19] McNair, L.D., Newswander, C., Boden, D., and Borrego, M. (2011). "Student and Faculty Interdisciplinary Identities in Self-Managed Teams." Journal of Engineering Education, 100(2), 374396.

[20] Richter, D.M., and Paretti, M.C. (2009). "Identifying barriers to and outcomes of interdisciplinarity in the engineering classroom." European Journal of Engineering Education 34(1), 29-45.

[21] Tucker, R. and Rollo, J. (2006). "Teaching and Learning in Collaborative Group Design Projects." Architectural Engineering and Design Management, 2:1-2, 19-30.

[22] Dutson, A., Todd, R., Magleby, S., \& Sorensen, C. (1997). Review Of Literature On Teaching Engineering Design Through Project Oriented Capstone Courses, Journal of Eng. Education, 86(1): 1725. 
[23] Solnosky, R. and Fairchild, J. (2017). "Survey Tools to Evaluate Multidisciplinary Team Dynamics in Capstone Courses", Advances in Engineering Education, (accepted) 